\title{
Testing for Competition in the Nigerian Commercial Banking Sector
}

\author{
Rufus Adebayo Ajisafe ${ }^{*}$, Anthony Enisan Akinlo \\ Department of Economics, Obafemi Awolowo University, Ile-Ife, Nigeria \\ Email: *rajisafe@oauife.edu.ng \\ Received April 9, 2013; revised May 9, 2013; accepted June 9, 2013
}

Copyright (C) 2013 Rufus Adebayo Ajisafe, Anthony Enisan Akinlo. This is an open access article distributed under the Creative Commons Attribution License, which permits unrestricted use, distribution, and reproduction in any medium, provided the original work is properly cited.

\begin{abstract}
The study determined the degree of competition in the banking sector between 1990 and 2009 using Panzar and Rosse (PR) methodology. The data for the study were obtained from the annual reports and statement of accounts of fifteen commercial banks in Nigeria which were purposively selected for the study. The data collected were analysed using dynamic panel generalised method of moment estimation technique with fixed effect. The results of the analysis showed that the Nigerian commercial banks were characterised by monopolistic competition with H-statistic significantly different from zero for all sample periods and sub-sample periods. The value of $\mathrm{H}$-statistic ranged between 0.0925 and 0.1168 . The study concluded that the banking industry in Nigeria exhibited monopolistic competition which supports the results obtained from previous studies in the developed economies.
\end{abstract}

Keywords: Banking; Competition; PR Model; Dynamic Panel; H-Statistic

\section{Introduction}

The Nigerian banking system has experienced some fundamental changes since independence. At independence, the banking markets were dominated by a relatively small number of foreign banks. After about three and half decades, the number of banks expanded and the ownership structure diversified. Initially, it was dominated by the public sector banks, and later (1992 to be specific), the private sector banks became the dominant participants. As at this period, the government intervened in the banking markets to control resource allocation and promote the indigenization policy of the economy. The policies of financial repression pursued by the government directed at the Central Bank of Nigeria (CBN) during this period, was to control interest rates, volume and direction of credit in the economy [1].

Less attention has been paid to the issue of competition in the financial sector but such competition matters for a number of reasons. In the first place, the degree of competition in the financial sector can affect the efficiency of the production of services, the quality of products, and the degree of innovation in that sector. Secondly, it has been observed theoretically that the degree

"Corresponding author. of competition in the financial sector can affect the access of firms to external financing [2]. Also, less competitive banking can be more costly thereby lowering the quality of services which invariably reduces the effective demand for external financing and thus reduces growth. These effects may further vary by the degree of competition in the country over financial sector [3].

The impact of competitive and regulatory changes on banks can be judged by gross measures of performance (efficiency) such as profitability and failure rates, but how such changes can affect the efficiency with which banks transform resources into various financial services are of vital importance to the economists. The development in technology has shaped the way in which banks carry out their business. That is, a new and improved technology in the banking system is expected to reduce bank cost over time. This has facilitated development of new, more sophisticated financial products as well as the introduction of alternative delivery channels to the traditional branch network [3]. This in conjunction with deregulation has intensified the financial sector competition in the industrialized nation. The question that arises from the above is that: what is the degree of competition in the Nigerian banking sector? The study intends to know whether the recent legal and institutional reforms in the 
sector were sufficient to transform the market structure into a more competitive mode or whether there are still some serious obstacles inherited from the earlier system that prevent the realization of competition. Thus, the objective of this study is to determine the degree of competition in the Nigerian banking sector.

In the remaining part of this paper, Section 2 focuses on the literature review, Section 3 discusses the model used in the study; while Section 4 gives the result of the analysis and Section 5 concludes the study.

\section{Literature Review}

Replete of literature abound on the degree of competition in the banking sector among which are Prasad and Ghosh (2005), Panzar and Rosse (PR) (1987), Bikker and Haaf (2001) and Claessens and Laeven (2004) among others.

[4] analysed whether competition has yielded significant benefits in terms of greater product sophistication and cost reduction. This was done by examining the degree of competition in the Indian banking system for the period 1996-2004 and the two-sub periods, 1996-1999 and 2000-2004. The study was carried out with the perception that competition in Indian banking sector has increased since the introduction of the financial sector reforms in 1992. The estimated model used interest revenue and total revenue as dependent variables and employed PR methodology in its estimation due to its advantage of using bank specific data and hence captures the unique characteristics of different banks. The results point to monopolistic behaviour of banks across time periods and across bank groups, with a more robust $\mathrm{H}$ statistic for the second sub-period and for private and foreign banks.

[5] argued that a higher degree of banking competition is a major issue for economic development and it is expected to provide welfare gains by reducing monopoly power of banks and cost inefficiencies, favoring the reduction of loan rates and then investment. The study used quarterly data for Czech banks, in order to provide evidence on the effects of banking competition in the Czech Republic. In the first place, the study measured the level and the evolution of banking competition between 1994 and 2005, using both the traditional IO approach and the new empirical IO approach. The traditional approach proposed structural test while the new empirical approach proposed the non-structural test. According to the traditional approach, competition was measured by concentration indices such as the market share of the five largest banks or the Herfindahl index calculated for total bank assets and loans. This approach suffers from the fact that they infer the degree of competition from indirect proxies such as market shares. The new empirical IO approach infers banks' conduct directly. The new ap- proach also takes into consideration the measure of contestability. The approach therefore uses the Rosse-Panzar model which is a non-structural test to measure the degree of competition using the $\mathrm{H}$-statistic which is the sum of the elasticities of total revenues to input prices. The authors find no improvement in banking competition during the transition period.

[6] examined competitive conditions and market structure in the banking industry, and investigate their interrelationship. That is, the study tested empirically the relationship between concentration and competition. Also, the study seeks to measure the degree of competition in the European banking markets. As a result of the deficiencies of the structural models, the study developed the non-structural models of competitive behaviour and applied the Panzar and Rosse (PR) model to measure the degree of competition without using explicit information about the structure of the market. The PR model assessed the elasticities of interest revenues with respect to changes in banks' input prices. In order to distinguish competitive behaviour on local, national and international markets, for each country, three sub samples were taken: small or local banks, medium-sized banks and large or international banks. For all the 23 countries considered in the estimation, the result showed the existence of monopolistic competition in the banking industry.

[7] examined what drives bank competition and was of the opinion that competition in the financial sectors matters for a number of reasons. They observed that the degree of competition in the financial sector can matter for the efficiency of the production of financial services, the quality of financial products and the degree of innovation in the sector. They used bank- level data, and applied the PR methodology of competitiveness to estimate the extent to which changes in input prices are reflected in revenues earned by specific banks in 50 countries' banking systems. The competitiveness measure was then related to indicators of countries' banking system structures and regulatory regimes. The study found out that systems with greater foreign bank presence and fewer activity restrictions in the banking sector were more competitive and that entry restriction on commercial banks could reduce competition. The study equally found out that more concentrated banks are more competitive. The above findings confirmed that contestability determines effective competition especially by allowing (foreign) bank entry and reducing activity restrictions on banks. While the result suggested that structure is less important for the competitive behaviour of the banking sector, it shows that competition policy in the financial sector is more complicated than perhaps previously thought. In part, this might be as a result of the financial service industries undergoing rapid changes, triggered by deregulation and technological advances. These changes have 
made the definition of a financial market and any particular financial service more complex, and may have made market structure indicators less valuable measures of the competitive nature of financial systems. Developing proper competitiveness test and methodologies will remain an important area of research and policy focus.

[8] examined the effect of the changes in the structure of the Jamaican economy on the banking industry. This study is relevant as a result of the consolidation trend in the industry following the financial crisis during this period. It was observed that increase in market concentration has significant implications for the level of competition as well as the welfare of the customers in the banking sector. In analysing the changes in the level of concentration and competition in the banking industry over the period, the study used the Herfindahl-Hirschman Index. The results from the analysis revealed that there was a slight increase in competition following financial liberalisation. It is to be noted that after the financial crisis in the mid 1990s, the industry became more concentrated which might suggest that there was a decline in competition among the banks. However, as a result of the ambiguity in the result obtained from the structural model, the study used a more robust PR methodology to measure the market power of the industry. The result from this alternative methodology revealed that competition fell slightly immediately following the liberalisation period. Furthermore it was revealed that the hypothesis of monopoly and perfect competition were both rejected in favour of monopolistic competition for the entire sample period. The interaction term used in capturing the changes in market power over time indicated that there was a steady decline in competition throughout the specified sample period.

[9] assessed the degree of bank competition and discussed efficiency with regard to banks' financial intermediation in Ghana. In the study they applied panel data to variables derived from a theoretical model and find support for the presence of a noncompetitive market structure in the Ghanaian banking system, possibly hampering financial intermediation. The economic costs of the noncompetitive behaviour might have been exacerbated by the persisting domestic financing needs of the government, making it captive to the banks' behaviour and fostering inefficiency in the banking system. Also, large deficit financing through the issuance of treasury bills has not only crowded out the private sector in capturing banks investments, but has also put pressure on interest rates, thereby making access to bank lending even more difficult for the private sector thus hampering private sector development. Therefore, further private sector development appears to be very much dependent upon sound fiscal adjustment, and the possible link between fiscal policy and the efficiency of the banking sys- tem should deserve further attention. The result of the study further indicated that consolidation of the Ghanaian banking sector is expected due to scale matters. Furthermore, barrier to competition on interest revenue is an indication that competition is stifled in the Ghanaian banking system. This could be as a result of the non transparent fee structure of the banks which help to shield the bank market structure from competition. Following from here, there is the need for further study in the area of competition and efficiency in the banking industry.

[10] analysed the competitive nature of the Tanzanian banking industry from 2004 to 2008 . Utilizing a rich bank level data set, the study employed the PR methodology to compute the competitive index, taking into account risk, efficiency, regulatory and macroeconomic factors. The result showed that banks in Tanzania earned their income under conditions of oligopolistic conduct. Moreover, the competitive index derived from an interest revenue equation was not significantly different from that obtained using an aggregate revenue measure. This suggests that the degree of contestability from traditional intermediation activities approximates overall bank behaviour. The overall message is that greater market contestability can be achieved by adopting measures aimed at stimulating competitiveness in the banking sector, including consolidating gains on the macroeconomic front and allowing more foreign bank entry so as to increase the spread of banking services.

[11] investigated the degree of bank competition in the euro area, the US and UK before and after the recent financial crisis, and revisits the issue whether the introduction of EMU and the euro have had any impact on bank competition. The results suggested that the level of bank competition converged across euro area countries in the wake of the EMU. The recent global financial crisis led to a fall in competition in several countries and especially where large credit and housing booms had preceded the crisis. The result obtained showed that the degree of competition in the US and UK banking sector support monopolistic competition. This corroborate the work of [7,12] which applied this method to a large sample of countries, finding evidence of monopolistic bank competition with varying degree across .countries.

[13] assessed the degree of competition and relative efficiency of the FYR Macedonia's banking system-a sector which has undergone a substantial amount of change since the mid-1990s. In their analysis, PR methodology was adopted to test for the degree of competition using quarterly data for the period 2002-2005 for 20 commercial institutions in Macedonia. In general, the results obtained show that competition in the banking sector remains relatively weak.

From the literature review, it was observed that major- 
ity of the banks in various countries exhibited monopolistic competition. To buttress the above literature, [14] found monopolistic competition for New York banks, [15] in his study of European banking using data for 1986-1989 found monopolistic competition for Spain, UK, France, Germany and monopoly for Italy. Also, [16] using 1992-1996 data obtained monopolistic competition for France, Germany, Italy and the US. The degree of competition has been tested in the European area, US and to some extent in Africa but to the best of our knowledge, it has not been tested in the Nigerian banking sector. Thus, there is the need for the study.

\section{The Empirical Model and Technique of Analysis}

\subsection{Empirical Model}

To measure the degree of competition, the study adopted the methodology of Panzar and Rosse (1987). The PR methodology developed from a general equilibrium market model relied heavily on the premise that competition is measured by the extent to which changes in factor input prices are reflected in firms' equilibrium revenues [17]. Let us consider the revenue and cost relationship facing a particular bank:

Thus,

$$
\begin{aligned}
& R_{i}=R_{i}\left(y_{i}, n_{i}, z_{i}^{R}\right) \\
& C_{i}=C_{i}\left(y_{i}, w_{i}, Z^{c}\right)
\end{aligned}
$$

Where:

$R_{i}=$ Total revenue of bank $i$;

$C_{i}=$ Total costs of banks $i$;

$y_{i}=$ Output of the bank $i$

$n=$ Number of banks;

$w_{i}=$ Vector of factor input prices of bank $i$;

$z_{i}^{R}=$ is the vector of $J$ exogenous variables affecting the revenue function;

$z_{i}^{e}=$ is the vector of $L$ exogenous variables affecting the cost function.

From Equations (1) and (2), profit is defined as:

$$
\Pi_{i}=R_{i}\left(y_{i}, n_{i}, Z^{R}\right)-C_{i}\left(y_{i}, w_{i}, Z^{c}\right)
$$

For profit to be maximized, marginal revenue must equal marginal cost [18]. Thus we differentiate Equation (3) with respect to the revenue and cost function and equate to zero as shown:

$$
\begin{gathered}
\prod_{i}(.)=\frac{d R_{i}}{d R_{i}\left(y_{i}, n, Z^{R}\right)}-\frac{d C_{i}}{d C_{i}\left(y_{i}, w_{i}, Z^{c}\right)}=0 \\
R_{i}^{1}\left(y_{i}, n_{i}, Z^{R}\right)=C_{i}^{1}\left(y_{i} w_{i} Z^{c}\right)
\end{gathered}
$$

From Equation (4), the profit maximization condition holds at the market equilibrium level.
Given that the profit maximizing output level representing the equilibrium value is defined as:

$$
y_{i}^{*}=y^{*}\left(Z_{i}^{R}, w_{i}, Z_{i}^{c}\right)
$$

Substituting Equation (5) into Equation (1) and assume that $n$ is endogenously determined in the model, then Equation (1) becomes:

$$
R_{i}^{*}=R^{*}\left(y_{i}^{*}, w_{i}, Z_{i}^{R}\right)
$$

Equation (6) is the reduced form for revenues of the representative bank which is the product of the equilibrium output of bank $i$ and the common price level.

It is important to note that market power is measured by the extent to which a change in factor input prices $(\partial w)$ is reflected in the equilibrium revenue $\left(\partial R^{*}\right)$ earned by the bank and the measure of competition defined as H-statistic formulated by PR evaluates the elasticity of total revenue with respect to changes in factor input prices $[4,9,17]$.

$$
H=\sum_{k=1}^{K}\left(\frac{d R_{i}^{*}}{d W_{k i}} \cdot \frac{W_{k i}}{R_{i}^{*}}\right)
$$

where $k$ is the number of factor input prices used, representing the price of capital, price of labour and price of fund respectively.

Empirically, if we write Equation (4) in mathematical form, and follow the work of [9] we have,

$$
\operatorname{Ln}\left(R_{i}^{1}\right)=\alpha_{0}+\alpha_{1} \operatorname{Ln}\left(y_{i}\right)+\sum_{J=1}^{J} d_{j} \operatorname{Ln}\left(Z_{j i}^{R}\right)
$$

and

$$
\operatorname{Ln}\left(C_{i}^{1}\right)=\beta_{0}+\beta_{1} \operatorname{Ln}\left(y_{i}\right)+\sum_{K=1}^{K} b_{k} \operatorname{Ln}\left(W_{k i}\right)+\sum_{l=1}^{L} V_{i} \operatorname{Ln}\left(Z_{l i}^{c}\right)
$$

The natural logarithms of the variables used in Equation (8) are taken, because it is assumed that, time series data have overall trends of exponential growth.

For profit maximizing bank, $\mathrm{MR}=\mathrm{MC}$, therefore Equation (8) becomes

$$
\begin{aligned}
& \alpha_{0}+\alpha_{1} \operatorname{Ln}\left(y_{i}^{*}+\sum_{j=1}^{J} d j \operatorname{Ln}\left(Z_{j i}^{R}\right)\right) \\
& =\beta_{0}+\beta_{1} \operatorname{Ln}\left(y_{i}^{*}\right)+\cdots+\sum_{K=1}^{K} b_{k} \operatorname{Ln}\left(W_{K i}\right)+\sum_{l=1}^{L} V_{l} \operatorname{Ln}\left(Z_{l i}^{c}\right)
\end{aligned}
$$

Rearranging Equation (9) and collecting the like terms gives

$$
\begin{aligned}
& \left(\alpha_{1}-\beta_{1}\right) \operatorname{Ln}\left(y_{i}^{*}\right)+\sum_{j=1}^{J} d j \operatorname{Ln}\left(Z_{j i}^{R}\right) \\
& =\left(\beta_{0}-\alpha_{0}\right)+\sum_{k=1}^{k} b_{k} \operatorname{Ln}\left(W_{k i}\right)+\sum_{l=1}^{L} V_{1} \operatorname{Ln}\left(Z_{l i}^{c}\right)
\end{aligned}
$$




$$
\begin{aligned}
\operatorname{Ln}\left(y_{i}^{*}\right)= & \left(\frac{1}{\alpha_{1}-\beta_{1}}\right)\left(\beta_{0}-\alpha_{0}\right)+\sum_{k=1}^{k} b_{k} \operatorname{Ln}\left(W_{k i}\right) \\
& +\sum_{l=1}^{L} V_{l} \operatorname{Ln}\left(Z_{l i}^{c}\right)-\sum_{j=1}^{J} d j \operatorname{Ln}\left(Z_{j i}^{R}\right)
\end{aligned}
$$

Equation (11) is a mathematical representation of Equation (4) written in log linear form.

It could be observed from Equation (6) that the reduced form equation for the revenue function is the product of the equilibrium output of the bank and its common prices $[9,18]$ written in logarithm form as shown in Equation (12).

$$
\operatorname{Ln}\left(R^{*}\right)=\operatorname{Ln}\left(y_{i}^{*} w^{*}\right) .
$$

Operationalising Equation (12) gives:

$$
\begin{aligned}
\operatorname{Ln}\left(R_{i t}^{*}\right)= & \alpha+\sum_{K=1}^{K} \beta_{k} \operatorname{Ln}\left(W_{k i}\right)+\mu \operatorname{Ln}\left(Y_{i}^{*}\right) \\
& +\sum_{q=1}^{Q} \rho \operatorname{Ln}\left(Z_{q i}\right)+\varepsilon_{i}
\end{aligned}
$$

where $z$ is a vector of exogenous and $Q$ bank specific characteristics without reference to their origin, either from cost or revenue functions. $Y^{*}$ is a scale variable which represents the output of the bank $i$ (Bank size), $W_{k i}$ is a vector of factor input prices, representing the price of labour, price of capital and price of fund respectively and $R^{*}$ is the equilibrium revenue scaled by the total asset of the bank. From Equation (13), we now evaluate our Hstatistic, which is now defined as:

$$
H=\sum_{K=1}^{K} B_{k}
$$

where $B_{k}$ represents the coefficients of the three dimensional factor input prices defined earlier on. The sign and magnitude of H-statistic matters in its interpretation. In a monopoly market structure, an increase in factor input prices $\left(W_{i}\right)$ will increase marginal cost thereby reducing equilibrium output $\left(Y^{*}\right)$ and invariably reduce the total revenue generated in that market. This implies that the value of $\mathrm{H}$-statistic is less than or equal to Zero $(H \leq O)$. For a perfectly competitive market, an increase in factor input prices will increase marginal costs as well as average costs by the same proportion. This may not have any effect on the equilibrium output of banks. As a result, inefficient banks are forced out of the market. This made the remaining firms to face increased demand which eventually leads to an increase in output prices and revenue in the same proportion as costs. The value of $\mathrm{H}-$ statistic is then equal to unity $(H=1)$. In the case of monopolistic competition, an increase in input prices will lead to a less than proportional increase in revenue, as the demand for banking facing individual banks is inelastic. The value of $\mathrm{H}$-statistic lies between 0 and $1[8,9,17,19]$.
It has been observed that one of the assumptions of the methodology of Panzar and Rosse that makes it valid for further analysis is that, the banking sector is assumed to be in equilibrium. In line with this assumption, an equilibrium test will be performed using Equation (15) (see [3,7-9].

$$
\begin{aligned}
\operatorname{Ln}\left(1+\mathrm{ROA}_{i t}\right)= & \alpha+\sum_{K=1}^{K} \beta k \operatorname{Ln}\left(W_{k i}\right)+\mu \operatorname{Ln}\left(Y_{i}\right) \\
& +\sum_{q=1}^{Q} \rho \operatorname{Ln}\left(Z_{q i}\right)+\Sigma i
\end{aligned}
$$

ROA is the unadjusted return on assets. $(1+\mathrm{ROA})$ is used as the dependent variable instead of ROA for the sake of convenience, since it is believed that ROA can take on small or negative values. The result of the equilibrium test obtained from equation 15 is then tested using F-statistic that the sum of $E=\beta_{1}+\beta_{2}+\beta_{3}=0 .{ }^{1}$ The main reason for this test is to be sure that, in equilibrium, returns on bank assets should not be statistically correlated with input prices.

\subsection{Techniques of Analysis}

In order to estimate our models in Equations (13) and (15), each of the variables used in the model are tested for stationarity using panel unit root test [20-23]. This is necessary because of the nature of our time series data. It has been observed that most of our time series data are not stationary at levels and that the series are adequately represented by first difference [24].

[25] developed a procedure utilizing pooled cross section time series data to test the null hypothesis that each individual time series contains a unit root against the alternative hypothesis that each time series is stationary. As both the cross section and time series dimensions of the panel grow large, the panel unit root test statistic has a limiting normal distribution. They concluded that the use of panel unit root tests may prove to be particularly useful in analyzing industry-level and cross country data. It was also observed that the pooling approach or panel based unit root tests yields higher test power than performing a separate unit root test for each individual.

Various approaches have been used in performing panel unit root tests. This include: $[23,25,26]$, Fisher-type tests using ADF and PP test, see [27-29].

In the process of estimating the models, we first employ the panel pooled least square estimate and then used the panel GMM to test for the robustness of the model. From Equation (13), we determine the degree of competition using the value of $\mathrm{H}$-statistic, while Equation (15) is an equilibrium test used for the validity of $\mathrm{H}$-statistic.

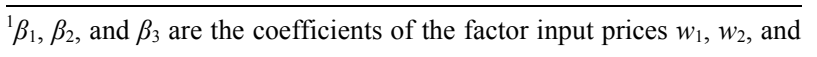
$w_{3}$. 


\subsection{Measurement of Variables}

In this section, the variables used in the estimation of our models are given appropriate definition. They are defined as used in Equations (13) and (15): $R^{*}$ is the equilibrium total revenue of the bank. It is proxied by the gross earnings scaled by the total assets of the bank. It is denoted by Geta in the model which represents the dependent variable. The total revenue of the banks is considered because the value of non-interest income has increased over the years. This view is supported among others by $[4,9$, 14]. In other to account for size differences, the total revenue is divided by total assets.

$w_{k i}$ is a vector of factor input prices, representing the price of labour, price of capital and price of fund respectively. In the estimated model, $w_{1}$ represents the price of labour which is measured as a ratio of personnel expenses to total asset or personnel expenses as a ratio of number of employee. In this study, the ratio of personnel expenses to total assets is considered as our indicator because there are missing data for the number of staffs for many banks. $w_{2}$ represents the price of capital which is the ratio of capital expenses to fixed asset, while $w_{3}$ represents the price of fund which is the ratio of interest expenses to total deposits $[2,8,17]$.

The output of the firm is measured by the amount of loans. The intermediation approach considers banks as financial intermediaries that convert deposits and borrowed funds into loans and investment. In this study, we consider only loan as our output variable which is measured in value terms. Other variables included in the study are bank specific factors which reflect differences in costs, size, risk, structure and product mix. The bank specific variables include: ratio of equity to total assets represented by $r_{1}$, ratio of loans to total assets represented by $r_{2}$, ratio of non-performing loans to total loans represented by $r_{3}$, the ratio of total deposit to total assets represented by TDTA, and total assets which is the scale variable represented by TA, controls for size of the bank and proxy for scale economies.

\section{Empirical Results}

\subsection{Result of Panel Unit Root Test}

The result of the Panel unit root tests are presented in Tables 1 and 2 respectively. Table 1 presents the result of the panel unit root test with individual effects while Table 2 presents the unit root test with individual effects and linear trends. All the variables used in the estimation of our model are in their log form. The two results are reported for comparison purposes. It could be observed from the tables that all the variables are stationary at levels. That is, they are integrated of order zero $I(0)$. Given the unit root property of the variables, we then proceed to the estimation of our model across full sample and
Table 1. Panel unit root test with individual effects.

\begin{tabular}{ccccc}
\hline Variables & LLC & Im, PS & ADF & PP \\
\hline \multirow{2}{*}{ Geta } & -5.1866 & -4.1368 & 70.2001 & 70.9097 \\
& $(0.0000)^{*}$ & $(0.0000)^{*}$ & $(0.0000)^{*}$ & $(0.0000)^{*}$ \\
\multirow{2}{*}{$w_{1}$} & -4.7746 & -4.3085 & 69.9997 & 66.8623 \\
& $(0.0000)^{*}$ & $(0.0000)^{*}$ & $(0.0000)^{*}$ & $(0.0001)^{*}$ \\
\multirow{2}{*}{$w_{2}$} & -3.6826 & -3.5804 & 65.2885 & 78.9850 \\
& $(0.0000)^{*}$ & $(0.0002)^{*}$ & $(0.0002)^{*}$ & $(0.0000)^{*}$ \\
\multirow{2}{*}{$w_{3}$} & -7.0522 & -4.9593 & 79.8558 & 78.3564 \\
& $(0.0000)^{*}$ & $(0.0000)^{*}$ & $(0.0000)^{*}$ & $(0.0000)^{*}$ \\
$r_{1}$ & -4.3766 & -3.7849 & 74.8309 & 88.3325 \\
& $(0.0000)^{*}$ & $(0.0001)^{*}$ & $(0.0000)^{*}$ & $(0.0000)^{*}$ \\
$r_{2}$ & -5.5761 & -3.8708 & 68.7083 & 52.9294 \\
& $(0.0000)^{*}$ & $(0.0000)^{*}$ & $(0.0001)^{*}$ & $(0.0060)^{*}$ \\
$r_{3}$ & -11.7358 & -6.2662 & 141.079 & 53.0870 \\
& $(0.0000)^{*}$ & $(0.0000)^{*}$ & $(0.0000)^{*}$ & $(0.0058)^{*}$ \\
TDTA & -4.0040 & -4.2909 & 74.6859 & 82.2604 \\
& $(0.0000)^{*}$ & $(0.0000)^{*}$ & $(0.0000)^{*}$ & $(0.0000)^{*}$ \\
\multirow{2}{*}{ TC } & -4.5110 & 0.7085 & 35.7271 & 72.3450 \\
& $(0.0000)^{*}$ & $(0.7607)$ & $(0.2171)$ & $(0.0000)^{*}$ \\
\multirow{2}{*}{ TA } & $-2,7858$ & 2.4463 & 28.0932 & 35.1073 \\
& $(0.0000)^{*}$ & $(0.9928)$ & $(0.5655)^{* * *}$ & $(0.2388)^{* *}$ \\
ROA & -5.3909 & -4.4541 & 71.1317 & 71.3469 \\
& $(0.0000)^{*}$ & $(0.0000)^{*}$ & $(0.0000)^{*}$ & $(0.0000)^{*}$ \\
\hline \multirow{2}{*}{$5 \% ;$} & $0 \%$ & & &
\end{tabular}

${ }^{*} 1 \% ;{ }^{* *} 5 \% ;{ }^{* * *} 10 \%$. This indicates rejection of null hypothesis of unit root. Probabilities for Fisher tests are computed using an asymptotic Chi-square distribution. All other tests assume asymptotic normality. LLC-Levin, Lin and Chu, Im, Ps-Im, Pesaran and Shin, ADF-Augmented Dickey Fuller, $\mathrm{PP}-$ Phillip Peron. The probability values are shown in parenthesis.

Table 2. Panel unit root test with individual effects and individual linear trends.

\begin{tabular}{ccccc}
\hline \multirow{2}{*}{ Variables } & LLC & Im, PS & ADF & PP \\
& -6.6115 & -4.8454 & 75.7351 & 75.2799 \\
Geta & $(0.0000)^{*}$ & $(0.0000)^{*}$ & $(0.0000)^{*}$ & $(0.0000)^{*}$ \\
& -4.3564 & -3.0586 & 58.0802 & 69.3816 \\
$w_{1}$ & $(0.0000)^{*}$ & $(0.0011)^{*}$ & $(0.0016)^{* *}$ & $(0.0001)^{*}$ \\
& -3.8412 & -2.0077 & 45.7881 & 52.9538 \\
$w_{2}$ & $(0.0000)^{*}$ & $(0.0223)^{* *}$ & $(0.0326)^{* *}$ & $(0.0060)^{* *}$ \\
& -5.3098 & -4.9991 & 79.0128 & 74.4125 \\
$w_{3}$ & $(0.0000)^{*}$ & $(0.0000)^{*}$ & $(0.0000)^{*}$ & $(0.0000)^{*}$ \\
& -4.1658 & -4.6474 & 71.8909 & 121.795 \\
$r_{1}$ & $(0.0000)^{*}$ & $(0.0000)^{*}$ & $(0.0000)^{*}$ & $(0.0000)^{*}$ \\
& -5.5629 & -3.9652 & 65.8378 & 42.1233 \\
$r_{2}$ & $(0.0000)^{*}$ & $(0.0000)^{*}$ & $(0.0002)^{*}$ & $(0.0699)^{* * *}$ \\
& -2.3228 & -3.3521 & 55.4353 & 95.3294 \\
$r_{3}$ & $(0.0101)^{*}$ & $(0.0004)^{*}$ & $(0.0032)^{* *}$ & $(0.0000)^{*}$ \\
& -5.3857 & -4.9420 & 75.8075 & 103.296 \\
TDTA & $(0.0000)^{*}$ & $(0.0000)^{*}$ & $(0.0000)^{*}$ & $(0.0000)^{*}$ \\
& -3.16775 & -1.6474 & 41.8319 & 28.8452 \\
TC & $(0.0008)^{*}$ & $(0.0497)^{* *}$ & $(0.0740)^{* * *}$ & $(0.5257)$ \\
& -5.3588 & -3.9667 & 67.6595 & 59.1609 \\
TA & $(0.0000)^{*}$ & $(0.0000)^{*}$ & $(0.0001)^{*}$ & $(0.0012)^{*}$ \\
& -6.3775 & -4.5513 & 69.6873 & 76.2273 \\
& $(0.0000)^{*}$ & $(0.0000)^{*}$ & $(0.0001)^{*}$ & $(0.0000)^{*}$ \\
\hline
\end{tabular}

${ }^{*} 1 \% ;{ }^{* *} 5 \% ;{ }^{* * *} 10 \%$. This indicates rejection of null hypothesis of unit root. Probabilities for Fisher tests are computed using an asymptotic Chi-square distribution. All other tests assume asymptotic normality. LLC-Levin, Lin and Chu, Im, Ps - Im, Pesaran and Shin, ADF-Augmented Dickey Fuller, $\mathrm{PP}$-Phillip Peron. The probability values are shown in parenthesis. 
sub-sample periods using both the pooled least square estimate and the GMM techniques.

\subsection{Results of Competition in the Banking Industry}

After the unit root test has been performed, and found out that our variables are stationary at levels, the model in equation 13 which is linear in its unknown parameters are then subjected to empirical investigation using panel data with fixed effects to account for any heterogeneity among the industry (banks) as well as to avoid specification problems. The common effect specification has been chosen for our model because the firms operating in the industry are country specific and they are likely to share the same characteristics. The model in Equation (13) is estimated using the Pooled Least Square and the result is presented in Tables 3-5.

It could be observed from the result presented that the banking sector in Nigeria exhibited a monopolistic competition over the entire sample period based on the value of H-statistic which lies between zero (0) and one (1). This is sufficed to say that the null hypothesis of perfect competition and monopoly is rejected at one percent level of significance, in favour of the alternative hypothesis, that the banking sector in the country is characterized by monopolistic competitive market. The Wald test performed on the significance of H-statistic showed that, it is statistically significant and different from zero and one with F-statistic of 29.5034 and 1688.343 at one percent (1\%) respectively (see Table 3 ).

The results as presented in Table 3 show that the price of loanable fund $\left(w_{3}\right)$ is positively related to the gross earnings and contributed the highest portion of the H-statistic for the entire period (1990-2009). This was

Table 3. Pooled least square estimate with fixed effects (19902009).

\begin{tabular}{ccc}
\hline Variables & \multicolumn{2}{c}{ Geta } \\
\hline $\mathrm{C}$ & Coefficient & t-statistic \\
$\log \left(w_{1}\right)$ & 0.651686 & $6.893248^{*}$ \\
$\log \left(w_{2}\right)$ & 0.018881 & $2.664913^{*}$ \\
$\log \left(w_{3}\right)$ & 0.059928 & 1.398503 \\
$\log (\mathrm{TA})$ & -0.005801 & $4.049425^{*}$ \\
$\log \left(r_{1}\right)$ & 0.018498 & -1.249893 \\
$\log \left(r_{2}\right)$ & 0.005493 & 1.349923 \\
$\log \left(r_{3}\right)$ & -0.007859 & 0.329003 \\
$\log (\mathrm{TDTA})$ & 0.067172 & -0.275876 \\
\hline
\end{tabular}

() Statistically significant at 1percent level. ( $^{* *}$ ) Statistically significant at 5 percent level. Summary statistics: $\mathrm{R}^{2}=0.2671 ; \mathrm{F}$-statistics $=3.909(0.000)$; $\mathrm{DW}=2.1770$; Schwarz criterion $=-1.7768 ; \mathrm{H}$-statistics $=0.1168$; F-statistic on Wald test for $H=0: 29.5034, \mathrm{p}$ value $=0.0000 ; \mathrm{F}$-statistic on Wald test for $H=1: 1688.343$, p value $=0.0000 ; H o: H=0$ (Monopoly); $H o: H=1$ (Perfect Competition); $H o: 0<H<1$ (Monopolistic Competition).
Table 4. Pooled least square estimate with fixed effects (19902004).

\begin{tabular}{|c|c|c|}
\hline \multirow[t]{2}{*}{ Variables } & \multicolumn{2}{|c|}{ Geta } \\
\hline & Coefficient & t-statistic \\
\hline $\mathrm{C}$ & 0.6236 & $4.1872^{*}$ \\
\hline $\log \left(w_{1}\right)$ & 0.0345 & $1.8181^{* * *}$ \\
\hline $\log \left(w_{2}\right)$ & 0.0156 & 0.9061 \\
\hline $\log \left(w_{3}\right)$ & 0.0584 & $2.8543^{*}$ \\
\hline $\log (\mathrm{TA})$ & -0.0032 & -0.46006 \\
\hline $\log \left(r_{1}\right)$ & 0.0325 & 1.5692 \\
\hline $\log \left(r_{2}\right)$ & 0.0011 & 0.0423 \\
\hline$\left(r_{3}\right)$ & -0.0112 & -0.2922 \\
\hline $\log ($ TDTA) & 0.0631 & $1.6388^{* * *}$ \\
\hline
\end{tabular}

(") Statistically significant at 1 percent level. $\left(^{* *}\right)$ Statistically significant at 5percent level. $\left.{ }^{* * *}\right)$ Statistically significant at 10 percent level. Summary statistics: $\mathrm{R}^{2}=0.1930 ;$ F-statistics $=4.1093(0.0100) ; \mathrm{DW}=2.2673$; Schwarz criterion $=-1.4376 ; \mathrm{H}$-statistics $=0.1085 ; \mathrm{F}$-statistic on Wald test for $H=0: 13.3222, \mathrm{p}$ value $=0.0003 ;$ F-statistic on Wald test for $H=1: 897.9538$, p value $=0.0000 ; H o: H=0$ (Monopoly); Ho: $H=1$ (Perfect Competition); Ho: $0<H<1$ (Monopolistic Competition).

Table 5. Pooled least square estimate with fixed effect (20052009).

\begin{tabular}{|c|c|c|}
\hline \multirow[t]{2}{*}{ Variables } & \multicolumn{2}{|c|}{ GETA } \\
\hline & Coefficient & t-statistic \\
\hline $\mathrm{C}$ & 0.50201 & $6.1423^{*}$ \\
\hline $\log \left(w_{1}\right)$ & 0.0085 & 0.7188 \\
\hline $\log \left(w_{2}\right)$ & 0.0089 & 0.6715 \\
\hline $\log \left(w_{3}\right)$ & 0.0751 & $8.8101^{*}$ \\
\hline $\log (\mathrm{TA})$ & -0.0036 & -0.7155 \\
\hline $\log \left(r_{1}\right)$ & -0.0064 & -0.8355 \\
\hline $\log \left(r_{2}\right)$ & 0.0059 & 0.7473 \\
\hline$\left(r_{3}\right)$ & 0.0117 & 0.4226 \\
\hline $\log$ (TDTA) & 0.1029 & $4.88803^{*}$ \\
\hline
\end{tabular}

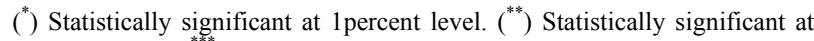
5percent level. $\left(^{* * *}\right)$ Statistically significant at 10 percent level. Summary statistics: $\mathrm{R}^{2}=0.90 ;$ F-statistics $=14.3500(0.0000) ; \mathrm{DW}=2.0176$; Schwarz criterion $=-4.516 ; \mathrm{H}$-statistics $=0.0925 ; \mathrm{F}$-statistic on Wald test for $H=$ $0: 31.7597, \mathrm{p}$ value $=0.0000 ;$ F-statistic on Wald test for $H=1: 3053.759, \mathrm{p}$ value $=0.0000 ; H o: H=0$ (Monopoly); Ho: $H=1$ (Perfect Competition); Ho: $0<H<1$ (Monopolistic Competition).

followed by the price of labour $\left(w_{1}\right)$ which is positively significant with a value of 0.037949 . This equally shows that labour is an important factor that influence the revenue earned by each bank. The coefficient of the price of capital $\left(w_{2}\right)$ was positive but not significant and consistently lower than the coefficient of the price of labour and price of fund. The non-significance of the price of capital could be as a result of high operating expenses and heavy fixed cost incurred during the sample period. In respect of the other explanatory variables in the model, the ratio of equity to total asset $\left(r_{1}\right)$ is positively related to the gross earnings (Geta). This implies that the banking industry in Nigeria supports risk taking in their port- 
folios in order to increase their earning capacity. It can be deduced that a higher level of risk capital leads to an increase in the gross earnings of the banking industry. The ratio of loans to total asset $\left(r_{2}\right)$ is positively related to the gross earnings (Geta). The positive sign on the $r_{2}$ coefficient is expected because accumulation of more loans reflects more potential income through interest revenue. The ratio of non-performing loan to total loans $\left(r_{3}\right)$ revealed a negative sign and is not significant. This shows that as the non-performing loan increases in value, the amount of income generated by the bank decreased. Total asset (TA) which is expected to have a positive relationship does not conform to a priori expectation. The result showed that total asset is negatively related to gross earnings. Total deposit as a ratio of total assets (TDTA) reported the right sign in its coefficient and statistically significant. This shows the importance of deposit in the balance sheet. As more deposits are received in the industry, the asset base of the industry expands, which eventually increase the income generated in the industry.

For robustness check, the time dimension of the sample period was divided into two, 1990-2004 and 20052009. The reason for the subdivision is to check whether there could be an improvement on the result, due to the reform introduced in the sector in 2004. Tables 4 and 5 depict the result of the subsample periods for 1990-2004 and 2005-2009. The two periods represents the pre and post reform era in the Nigerian banking industry. The period 1990-2004 marked the period of bank liquidation while the 2005-2009 coincided with the period when Nigerian bank recapitalized which marked a serious reformation in the sector.

In the pre-consolidation era, the result obtained for the period is not encouraging. The result showed that the price of loanable fund is statistically significant and possessed the appropriate sign with t-statistic of 2.854. Also, it contributed the highest coefficient of the H-statistic with 0.0584 . The value of the $\mathrm{H}$-statistic as obtained from the table is 0.1085 which is statistically different from zero (0) and one (1). It shows that the banking industry in Nigeria for that period exhibits monopolistic competition which supports the result obtained from other studies (see [8,30,31]). To corroborate the significance of the H-statistic, the F-statistic obtained from the Wald test is highly significant at one percent with a value of 13.222 and 897.9538 for $H=0$ and $H=1$ respectively (see Table 4). Total deposit as a ratio of total asset (TDTA) is statistically significant at $10 \%$ level of significance with a value of 1.6387 and conforms to a priori expectation. Other factor prices (prices of capital and price of labour) also conform to a priori expectation but their contributions to gross earnings are very low, though not significantly different from the entire sample period. The price of labour is significant at 10 percent and increases the revenue earnings of the bank by about 0.04 percent. The low contribution of the factor inputs is due to the fact that most of the banks as at this period are weak in terms of capital inadequacy, violation of banking law, rules and regulations, and lack of proper management among others.

The result of the second sub-sample period (20052009) is presented in Table 5. The result shows that price of fund is statistically significant and conform to a priori expectation. The variable is significant because of the increase in the level of deposit in the banking industry as a result of the introduction of the reforms in the sector. The reform in the sector possibly led to the effective mobilization of saving for investment purposes, which ultimately boosted increased in the deposits of the banking sector. The price of capital and price of labour conform to a priori, but not significant. The value of the H-statistic is 0.09254 which is slightly lower than the pre consolidation period (1990-2004). It was observed from the result that all the variables follow the same trend as in the first sub sample period and the entire sample period (1990-2009). The ratio of deposit to total asset is highly significant in all the period which shows the importance of deposit in the banking industry.

\subsection{Generalized Least Squares Estimation}

One of the assumptions underlying Ordinary Least Squares Estimation (OLSE) is that the mean and variance are constant and that errors are uncorrelated with one another $[23,27]$. But when using cross section data, this assumption may not be true since it is possible for the variances of the observations to differ from each other. When this happens, we say that the random variable and the random error are heteroskedastic. The cross section heteroskedasticity allows for a different residual variance for different cross section (Eviews 7, pg. 304). To allow for a different variance for each bank, we estimate equation 13 using cross section weights. The result of the estimation is as shown in Table 6. The results in Table 6 showed that all the independent variables are statistically significant and positively related to gross earnings (total revenue) of the banks with the exception of the scale variable (TA) which is negatively significant. The $R^{2}$ is very high with a value of 0.7278 , meaning that the variation of the explanatory variable with respect to the dependent variable is about $73 \%$. The F-statistic is also highly significant at $1 \%$ level. The Durbin Watson statistic is also close to 2 , which show that there is no serial correlation among the variables. The result showed that bank specific characteristics or weights is very important in determining the relationship between the factor prices (price of labour, price of capital and price of fund) and the total revenue of the banks. Furthermore, the H-statistic value ranges between zero and one which supports the 
Table 6. Pooled generalised least square estimate with cross section weight (1990-2009).

\begin{tabular}{ccc}
\hline Variables & \multicolumn{2}{c}{ GETA } \\
\hline C & Coefficients & t-statistic \\
$\log \left(w_{1}\right)$ & 0.5955 & $16.5828^{*}$ \\
$\log \left(w_{2}\right)$ & 0.0159 & $3.7758^{*}$ \\
$\log \left(w_{3}\right)$ & 0.0546 & $3.1350^{*}$ \\
$\log (\mathrm{TA})$ & -0.0067 & $10.1115^{*}$ \\
$\log \left(r_{1}\right)$ & 0.0182 & $-3.9357^{*}$ \\
$\log \left(r_{2}\right)$ & 0.0109 & $3.7937^{*}$ \\
$\left(r_{3}\right)$ & 0.0010 & $1.8186^{* * *}$ \\
$\log (\mathrm{TDTA})$ & 0.0647 & 0.1105 \\
\hline
\end{tabular}

(") Statistically significant at 1percent level. $\left(^{* *}\right)$ Statistically significant at 5 percent level. $\left({ }^{* * *}\right)$ Statistically significant at 10 percent level. Summary weighted statistics: $\mathrm{R}^{2}=0.7279$; F-statistics $=28.6965(0.0000)$; $\mathrm{DW}=$ 1.8093; H-statistics $=0.0925 ;$ F-statistic on Wald test for $H=1: 1329.01, \mathrm{p}$ value $=0.0000 ; H o: H=0$ (Monopoly); Ho: $H=1$ (Perfect Competition); Ho: $0<H<1$ (Monopolistic Competition).

previous results of monopolistic competition with a value of 0.092592 . The F-statistic obtained from the Wald test showed that the null hypothesis of $H=0$ and $H=1$ are rejected at one percent level of significance with a value of 138.3748 and 13290.01 respectively.

\subsection{Generalized Method of Moment Estimates (GMM)}

As a robustness check, we estimate Equation (13) using the Generalised Method of Moment (GMM) estimation technique. A fundamental assumption of regression analysis is that the right hand side of a model is uncorrelated with the disturbance term. If this assumption is violated, both ordinary least square and weighted least square are biased and inconsistent. Where the right hand side is correlated with the residual, instrumental variable regression can be estimated. One of the approaches adopted is the use of Generalized Method of Moments (GMM). GMM generally account for heteroskedasticity and serial correlation between exogenous variables and the disturbance term. The GMM specification used in this study is based on orthogonally condition between a function and instruments. The study employed the Arellano-Bond estimation with lagged endogenous variable and cross section fixed effect. In the study, period specific predetermined instruments were used to indicate that the number of instruments expand dynamically over time. Aside, the technique allows us to relax the assumption of strict exogeneity of pooled least square estimation technique.

The results of the Generalised Method of Moment (GMM) estimate is reported in Table 7 for the full sample period (1990-2009) which confirmed the result of the generalized least square estimate in Table 6. The factor prices: price of labour $\left(w_{1}\right)$, price of capital $\left(w_{2}\right)$ and price
Table 7. Panel generalised method of moments with fixed effects.

\begin{tabular}{ccc}
\hline VARIABLES & \multicolumn{2}{c}{ GETA } \\
\hline & Coefficients & t-statistic \\
GETA $(-1)$ & 0.0790 & 1.2562 \\
$\log \left(w_{1}\right)$ & 0.0181 & $2.1300^{* *}$ \\
$\log \left(w_{2}\right)$ & 0.0128 & 1.7237 \\
$\log \left(w_{3}\right)$ & 0.0599 & $8.0387^{*}$ \\
$\log (\mathrm{TA})$ & -0.0090 & $-3.2110^{*}$ \\
$\log \left(r_{1}\right)$ & 0.0097 & 1.2018 \\
$\log \left(r_{2}\right)$ & 0.0145 & 1.4259 \\
$\left(r_{3}\right)$ & -0.0021 & -0.0856 \\
$\log (\mathrm{TDTA})$ & 0.0828 & $4.3367^{*}$ \\
\hline
\end{tabular}

$\left(^{*}\right)$ Statistically significant at 1percent level. $\left(^{* *}\right)$ Statistically significant at 5percent level. $\left.{ }^{* * *}\right)$ Statistically significant at 10 percent level. J-statistic $=$ 115.8269; Instrument rank $=148 ; \mathrm{H}$-statistics $=0.0908 ;$ F-statistic on Wald test for $H=0: 33.9453$, p value $=0.0000 ;$ F-statistic on Wald test for $H=1$ : 4706.536, p value $=0.0000 ; H o: H=0$ (Monopoly); Ho: $H=1$ (Perfect Competition); Ho: $0<H<1$ (Monopolistic Competition).

of fund $\left(w_{3}\right)$ are all significant and conform to a priori expectation. The price of fund is positive and significant with a t-value of 8.0387 and coefficient value of 0.059930 . The price of capital is also significant at $10 \%$ with a $\mathrm{t}$-value of 1.7237 and coefficient value of 0.012838 while the price of labour is also positive and significant with a $\mathrm{t}$-value of 2.1300 and coefficient value of 0.018054 . The lagged endogenous variable (Geta) is positively related not significant. It shows that the revenue earned by the bank in the previous period is positively related to the revenue earned in the current period, but with little impact on the total revenue. All other variables follow the trends observed in Table 3. Moreover, from the result in Table 7, the value of our H-statistic is 0.0908 , which is the sum of elasticities of banks equilibrium revenue with respect to the factor input prices, that is, the sum of the coefficients of price of labour, price of capital and price of funds as shown in Equation (14). This value confirmed the result of the other $\mathrm{H}$-statistic obtained in this study. This means that commercial banks in Nigeria is characterised by monopolistic competition but the level of competition is too low as observed by [30] which reports a low H-statistic for Austria (0.154) and Denmark $(0.050)$. The price of fund $\left(w_{3}\right)$ contributed the highest value of the H-statistics which support the Pooled OLS and generalized least square estimate.

From the result of our H-statistic, it could be observed that the result is consistent with previous studies which support monopolistic competition. Furthermore, our results also support the fact that, price of capital contributes minimally to total revenue when compared to other input prices. This is the least important component of $\mathrm{H}-$ statistics see $[8,15]$. The values of the J-statistic and instrument rank showed that the instrument used is valid since the value of the instrument rank (148) is greater 
than the number of estimated coefficient (9). The J-statistic calculated is 0.924355 . When compared with the values of the following information criteria $(\mathrm{BIC}=0.982$, $\mathrm{HQIC}=0.966$, RNIC $=0.986$ ) in order to determine the validity of the instrument, it was then concluded that the instrument used is valid. The model selection criteria perform reasonably well for sample sizes above 250 .

\subsection{Market Equilibrium Test for H-Statistic}

An important feature of the $\mathrm{H}$-statistic is that equilibrium tests must be performed on observations that are in longrun. The equilibrium test is suggested based on the fact that, in equilibrium, rates of return across banks should not be correlated statistically with input prices [30]. To test whether this assumption holds in the case of Nigeria, we remodeled the PR methodology by using the return on asset as proposed in the literature [3,9,30].

It should be noted that, the measure of ROA can take on negative values on some occasion due to banks' losses in any year, thus, the variable is adjusted simply for the small negative values and computed as $(1+\mathrm{ROA})$ for convenience. Equation (15) is then estimated for the market equilibrium test. The results obtained from the pooled data revealed that the market is in equilibrium based on the value of H-statistic of 0.043055 with F-statistic of 43.3222 and $p$ value of 0.0000 obtained from the Wald test. This is statistically significant and different from zero and one at $1 \%$ level (see Table 8). The results from the equilibrium test also show that all the factor input prices are positively related to return on asset and statistically significant with the exception of the price of capital. The price of labour $\left(w_{1}\right)$ contributes mostly to the value of $H$ in contrast to our previous results in which the

Table 8. Pooled generalised least square estimate with cross section weights (Equilibrium Test).

\begin{tabular}{ccc}
\hline \multirow{2}{*}{ Variables } & \multicolumn{2}{c}{$1+$ ROA } \\
\cline { 2 - 3 } & Coefficients & t-statistic \\
\hline $\mathrm{C}$ & 0.3780 & $12.1189^{*}$ \\
$\log \left(w_{1}\right)$ & 0.0253 & $5.1205^{*}$ \\
$\log \left(w_{2}\right)$ & 0.0067 & 1.5287 \\
$\log \left(w_{3}\right)$ & 0.0110 & $2.3391^{* *}$ \\
$\log (\mathrm{TA})$ & -0.0054 & $-3.6304^{*}$ \\
$\log \left(r_{1}\right)$ & 0.0118 & $2.8802^{*}$ \\
$\log \left(r_{2}\right)$ & 0.0077 & 1.4301 \\
$\left(r_{3}\right)$ & -0.0011 & -0.1336 \\
$\log (\mathrm{TDTA})$ & 0.0218 & $2.3481^{* *}$ \\
\hline
\end{tabular}

(") Statistically significant at 1percent level. $\left(^{* *}\right)$ Statistically significant at 5percent level. $\left.{ }^{* * *}\right)$ Statistically significant at 10 percent level. Summary weighted statistics: $\mathrm{R}^{2}=0.4519$; F-statistics $=8.8475(0.0000)$; DW $=$ 1.2960; H-statistics $=0.04305 ;$ F-statistic on Wald test for $H=0: 43.3222, \mathrm{p}$ value $=0.0000 ;$ F-statistic on Wald test for $H=1: 15458, \mathrm{p}$ value $=0.0000$; $H o: H=0$ (Monopoly); $H o: H=1$ (Perfect Competition); Ho: $0<H<1$ (Monopolistic Competition). price of fund contributes the highest coefficient to H-statistic. This implies that as a result of an increase in the price of labour, they are encouraged to improve on their capacity, which invariably increases their contribution to the total revenue of the industry (banks net income). Based on our calculation of H-statistic, the result obtained from our estimation of equilibrium test shows that our observations are in equilibrium. This is premised on the value of $\mathrm{H}$-statistic reported earlier $(H=0.04305)$. This value is closer to zero than one (1). This implies the rejection of the null hypothesis of $H=0$ and $H=1$ at 1 percent level of significance.

Other variables in the model are statistically significant with the exception of non-performing loans $\left(r_{3}\right)$. This is because some of the loans granted by the banks to individuals or firms were diverted to other uses rather than what they were meant for which made the repayment difficult.

\section{Conclusion}

Competition in the banking sector has received greater attention of the economists in recent years but the degree of competition has generated a serious debate both in the developed and developing economies. It has been observed in the literature that a higher degree of competition in banking industry is expected to provide welfare gains through reduction in the prices of factor input and thereby accelerating growth. From the empirical analysis of the study, it was observed that commercial banks in Nigeria showed evidence of monopolistic competition which corroborate the result obtained in the previous studies. ${ }^{2}$ The result obtained is in contrast to the theory which emphasizes oligopolistic nature of the industry because of the dominance of some banks in the industry.

\section{REFERENCES}

[1] M. Brownbridge, "The Impact of Public Policy on the Banking System in Nigeria," 1996.

[2] L. Weill, "On the Relationship between Competition and Efficiency in the EU Banking Sectors," Kredit und Kapital, Vol. 37, No. 3, 2003, pp. 329-352.

[3] S. Claessens and L. Laeven, "Financial Dependence, Banking Sector Competition, and Economic Growth," World Bank Policy Research Working Paper, No. 3481, 2005.

[4] A. Prasad and S. Ghosh, "Competition in Indian Banking," IMF Working Paper, 2005.

[5] L. Weill, A. Pruteanu-Podpiera and F. Schobert, "Banking Competition and Efficiency: A Micro-Data Analysis on the Czech Banking Industry," Comparative Economic Studies, Vol. 50, No. 2, 2008. pp. 253-273. doi:10.1057/palgrave.ces.8100248

${ }^{2}$ Shaffer 1982, Molyneux etal 1994, Prasad and Gosh 2005, Buchs and Mathisen 2005 among others. 
[6] J. A. Bikker and K. Haaf, "Competition, Concentration and Their Relationship: An Empirical Analysis of the Banking Industry," Journal of Banking and Finance, Vol. 26, No. 11, 2002, pp. 2191-2214. doi:10.1016/S0378-4266(02)00205-4

[7] S. Claessens and L. Laeven, "What Drives Bank Competition? Some International Evidence," Journal of Money Credit and Banking, Vol. 36, No. 3, 2004, pp. 563-583. doi:10.1353/mcb.2004.0044

[8] D. Denvil, "Testing for Competition in the Jamaican Banking Sector: Evidence from Bank Level Data," Financial Stability Unit, Bank of Jamaica, 2002.

[9] T. Buchs and J. Mathisen, "Competition and Efficiency in Banking: Behavioural and Evidence from Ghana," IMF Working Paper, International Monetary Fund, 2005.

[10] A. M. Simpasa, "Competitive Conditions in the Tanzania Commercial Banking Industry," African Development Review, Vol. 23, No. 1, 2011, pp. 88-98. doi:10.1111/j.1467-8268.2010.00274.x

[11] Y. Sun, "Recent Developments in European Bank Competition," International Monetary Fund Working Paper, 2011.

[12] J. A. Bikker and L. Spierdijk, "How Banking Competition Changed Overtime," Tjalling C. Koopmans Research Institute, Discussion Paper Series, No. 08-04, 2008.

[13] G. Alessandro and R. Kevin, "Bank Competition and Efficiency in the FYR Macedonia," South-Eastern Europe Journal of Economics, Vol. 2, 2008, pp. 145-167.

[14] S. Shaffer, "A Non-Structural Test for Competition in Financial Markets," In: Proceedings of a Conference in Bank Structure and Competition, Federal Reserve Bank of Chicago, Chicago, 1982.

[15] P. Molyneux, Y. Altunbas and E. Gardener, "Efficiency in European Banking," Wiley, Chichester, 1996.

[16] O. De Bandt and Philip E. Davis, "Competition, Contestability and Market Structure in European Banking Sectors on the Eve of EMU," Journal of Banking and Finance, Vol. 24, No. 6, 2000, pp. 1045-1066. doi:10.1016/S0378-4266(99)00117-X

[17] J. C. Panzar and J. N. Rosse, "Testing for Monopoly Equilibrium," Journal of Industrial Economics, Vol. 35, No. 4, 1987, pp. 443-456. doi:10.2307/2098582

[18] A. Kuotsoyiannis, "Modern Microeconomics," International Edition, Macmillian Press Ltd., London, 2003.
[19] C. A. Northcott, "Competition in Banking: A Review of the Literature," Bank of Canada Working Paper, 2004-24, 2004.

[20] J. M. Wooldridge, "Introductory Econometrics: A Modern Approach," South-Western College Publishing, Cincinnati, 2000.

[21] R. S. Pindyck and D. L. Rubinfeld, "Econometric Models and Economic Forecasts," McGraw-Hill, Singapore City, 1997.

[22] K. S. Pesaran and Y. Shin, "Testing for Unit Roots in Heterogeneous Panels," Journal of Econometrics, Vol. 115, No. 1, 2003, pp. 53-74. doi:10.1016/S0304-4076(03)00092-7

[23] W. H. Greene, "Econometric Analysis," 6th Edition, Prentice-Hall, Upper Saddle River, 2008.

[24] R. C. Hill, W. E. Griffiths and G. C. Lim, "Principles of Econometrics," 3rd Edition, John Wiley and Sons, Inc., New York, 2007.

[25] A. Levin, C. F. Lin and C. Chu, "Unit Root Tests in Panel Data: Asymptotic and Finite Sample Properties," Journal of Econometrics, Vol. 108, No. 1, 2002, pp. 1-24. doi:10.1016/S0304-4076(01)00098-7

[26] B. Baltagi, Eds., "Root Test for Panel Data," In: Advances in Econometrics, Vol. 15: Nonstationary Panels, Panel Cointegration, and Dynamic Panels, JAI Press, Amsterdam, pp. 161-178.

[27] G. S. Maddala and S. Wu, "A Comparative Study of Unit Root Tests with Panel Data and a New Simple Test," Oxford Bulletin of Economics and Statistics, Vol. 61, No. S1, 1999, pp. 631-652. doi:10.1111/1468-0084.61.s1.13

[28] I. Choi, "Unit Root Tests for Panel Data," Journal of International Money and Finance, Vol. 20, No. 2, 2001, pp. 249-272. doi:10.1016/S0261-5606(00)00048-6

[29] K. Hadri, "Testing for Stationarity in Heterogeneous Panel Data," Econometric Journal, Vol. 3, No. 2, 2000, pp. 148-161. doi:10.1111/1368-423X.00043

[30] B. Casu and C. Girardone, "Does Competition Leads to Efficiency? The Case of EU Commercial Banks," Discussion Paper, Essex Finance Centre, 2007.

[31] L. G. de Rozas, "Testing for Competition in the Spanish Banking Industry: The Panzar-Rosse Approach Revisited," Documentos de Trabajo, No. 0726, 2007. 